\title{
Feeding and oviposition deterrent activities of microencapsulated cardamom oleoresin and eucalyptol against Cydia pomonella
}

\author{
Orkun Baris Kovanci ${ }^{1 *}$
}

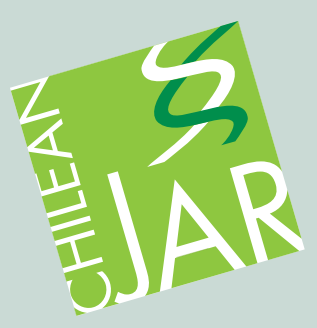

\section{ABSTRACT}

Behavioral manipulation of insects with spice-based deterrents may provide an alternative control strategy. Microencapsulation technology could lead to more effective use of spice essential oils and oleoresins in the field by extending their residual activity. The feeding and oviposition deterrent potential of the microencapsulated cardamom (Elettaria cardamomum [L.] Maton) oleoresin (MEC-C) and eucalyptol (MEC-E) were evaluated against codling moth, Cydia pomonella Linnaeus, 1758. MEC-C capsules contained both 1,8 -cineole and $\alpha$-terpinyl acetate, whereas MEC-E capsules contained only 1,8-cineole. In larval feeding bioassays, MEC-E exhibited the lowest feeding deterrent activity (33\%) while MEC-C at $100 \mathrm{mg} \mathrm{mL}^{-1}$ had the highest $(91 \%)$. The highest oviposition deterrence activity against gravid females was also shown by MEC-C at $100 \mathrm{mg} \mathrm{mL}^{-1}$ with $84 \%$ effective repellency. In 2010 and 2011, two apple orchards were divided into four 1 ha blocks and sprayed with the following treatments in ultralow volume sprays: (a) MEC-E at $100 \mathrm{~g} \mathrm{~L}^{-1}$, (b) MEC-C at $50 \mathrm{~g} \mathrm{~L}^{-1}$, (c) MEC-C at $100 \mathrm{~g} \mathrm{~L}^{-1}$, and (d) MEC-pyrethrin at $15 \mathrm{~mL} \mathrm{~L}^{-1}$. Water-treated abandoned orchards were used as negative controls. Moth catches were monitored weekly using Ajar traps baited with the combination of codlemone, pear ester, and terpinyl acetate. Based on pooled data, mean cumulative moth catch per trap per week was significantly higher in the MEC-E blocks (26.3 male and 13.5 female moths) than those in other treatments except the abandoned blocks. At mid-season and pre-harvest damage assessment, the percentage of infested fruits with live larvae in the high dose MEC-C-treated blocks was reduced to $1.9 \%$ and $2.3 \%$ in 2010 and to $1.1 \%$ and $1.8 \%$ in 2011 , respectively. Since fruit damage exceeded the economic damage threshold of $1 \%$, high-dose MEC-C treatment may only offer supplementary protection against codling moth in integrated pest management programs.

Key words: 1,8-Cineole, microcapsule, spice, $\alpha$-terpinyl acetate, Ultra-low volume.

${ }^{1}$ Uludag University, Faculty of Agriculture, Bursa 16059, Turkey. "Corresponding author (baris@uludag.edu.tr).

Received: 22 January 2015.

Accepted: 31 July 2015

doi:10.4067/S0718-58392016000100009

\section{INTRODUCTION}

Codling moth (Cydia pomonella Linnaeus, 1758) has been the key pest of apples, pears, and walnuts worldwide since its first account in 1635. Factors such as insecticide resistance and climate change have made codling moth control increasingly difficult to achieve (Lethmayer et al., 2009). Hence, there is still a need for alternative management strategies to obtain safe and reliable control of the codling moth. Behavioral manipulation of codling moth with spice-based deterrents may provide an alternative control strategy.

Since ancient times, spices have been used not only as flavoring agents and food preservatives but also as natural repellents and pesticides (Romeo et al., 2010; Campolo et al., 2014). Most spice plants get their distinct flavor characteristics from essential oils that also show antioxidant and pesticidal activities. In fact, even pleasant-smelling spices such as mint, rosemary, and thyme possess insecticidal properties due to the interference of essential oils with the octopaminergic nervous system of insects (Isman, 2006).

Spice essential oils contain a complex mixture of volatile monoterpenes, sesquiterpenes, and phenols, which play important defensive roles against insect herbivory (Isman, 2006). Some of these essential oil constituents were found to exhibit contact or fumigant toxicity, while others had only insect repellent, and antifeedant effects (Isman, 2000; Sedy and Koschier, 2003; Kanat and Alma, 2004; Nerio et al., 2010; Caballero Gallardo et al., 2011).

The cardamom (Elettaria cardamomum [L.] Maton) from the ginger family (Zingiberaceae) is considered as the queen of spices in India. Its seeds contain a clear to pale yellow essential oil with a pungent odor. The cardamom oil is mainly composed of two major constituents, 1,8-cineole and $\alpha$-terpinyl acetate, up to $50 \%$ each (Weiss, 2002). It was reported to be toxic to different life stages of the coleopteran and lepidopteran stored-product pests through contact and fumigant actions (Abbasipour et al., 2011).

Apart from cardamom, 1,8-cineole, also known as eucalyptol, is found in other plants such as eucalyptus (Eucalyptus globulus Labill.) and rosemary (Rosmarinus officinalis L.) Studies with essential oils extracted from various plants revealed the feeding deterrent effects of 1,8-cineole on neonate larvae of the codling moth (Suomi et al., 1986; Landolt et al., 1999; Durden et al., 2009). This compound has also been used to repel or control adult stages of urban insect pests, including bed bugs, chiggers, cockroaches, flies, mosquitoes, and stored-product beetles (Tripathi et al., 2009). 
Unlike 1,8-cineole, $\alpha$-terpinyl acetate, when mixed with brown sugar solution, is attractive to both sexes of adult codling moth and Oriental fruit moth (Grapholita molesta Busck, 1916) (Kovanci and Walgenbach, 2005). In addition, low-dose application of $\alpha$-terpinyl acetate can synergize attraction of Oriental fruit moth males to sex pheromone (Il'ichev et al., 2009). However, attractants at low doses may become repellents at high doses as in the case of $\alpha$-terpinyl acetate for Bombyx mori (Linnaeus, 1758) larvae (Hamamura and Naito, 1961; Ito and Horie, 1962). The effect of highdose $\alpha$-terpinyl acetate treatments on host location by adult and larval codling moth is unknown.

The binary mixture of essential oil constituents may result in synergistic, antagonistic or additive effects on target pests (Miresmailli et al., 2006). Synergy was reported for binary mixtures of various monoterpenoid antifeedants (Hummelbrunner and Isman, 2001). Binary mixtures of 1,8 -cineole with $\alpha$-terpineol was shown to be more deterrent than the individual compounds alone against Chilo partellus (Swinhoe 1885) larvae (Singh et al., 2009). Such synergy between monoterpenoid antifeedants has not been demonstrated for $C$. pomonella larvae.

Among the major drawbacks of plant essential oils are their quick evaporation and rapid degradation under sunlight (Isman, 2000). Solvent-extracted spices, called oleoresins, are more stable than essential oils because of their high antioxidant content (Krishnan et al., 2005). Yet, spice oleoresins may still show sensitivity to light, heat, and oxygen. One way to protect the oleoresin from adverse environmental conditions is the use of a microencapsulation process. Microencapsulation also converts essential oils and oleoresins into a free-flowing powder form that is suitable for water-soluble applications (Shaikh et al., 2006).

The efficient use of microencapsulated formulations relies on the deposition of sufficient amount of microcapsules in the tree canopy. Low-volume applications have proven successful in placing microencapsulated pheromone formulations on target more effectively and economically than high-volume applications (Knight et al., 2008; Kovanci et al., 2010). So far, however, no study has examined the performance of microencapsulated essential oils and oleoresins applied at an ultra-low volume rate of less than $50 \mathrm{~L}$ water $\mathrm{ha}^{-1}$ for tree crops.

The objectives of this study were to evaluate the feeding and oviposition deterrent potential of the microencapsulated cardamom oleoresin and eucalyptol applied in ultra-low volume sprays against codling moth larvae and adults.

\section{MATERIALS AND METHODS}

\section{Insects}

Codling moth pupae were obtained from the laboratory susceptible populations reared on artificial pinto-bean based diet (Shorey and Hale, 1965) at the Department of Biology in University of Kaiserslautern, Germany. Colonies were collected from conventional apple (Malus domestica Borkh.) orchards in the Bodensee Region (Lake Constance), BadenWürttemberg in 2007. Pupae were stored at $25^{\circ} \mathrm{C}$ and 70 $80 \% \mathrm{RH}$ under a long-day photoperiod 16:8 h. Polypropylene ziploc bags served as an oviposition substrate for moths. Neonates used for bioassays were collected following 0.5 $1.0 \mathrm{~h}$ after hatch.

\section{Chemicals}

Dried powder microcapsules of eucalyptol (MEC-E, Graphic Scents Direct, CoverScent,Amsterdam, The Netherlands), which was the main component isolated from Rosmarinus officinalis oil, were used in this study. These gelatin-based microcapsules were composed of 90\% 1,8-cineole and other inert ingredients including antioxidants and UV stabilizers. They can easily be mixed in water and used for spray applications.

The microencapsulated cardamom oleoresin (MEC-C) formulation consisted of 30\% 1,8-cineole, 50\% $\alpha$-terpinyl acetate, and other non-volatile components such as fixed oils, antioxidants, and pigments in powder form; it was obtained from Synthite Chemicals, Kerala, India. MEC-C capsules were reported to exhibit good residual activity with $82 \%$ and $86 \%$ of their 1,8-cineole and $\alpha$-terpinyl acetate content remaining, respectively, after a period of 6 wk at $25^{\circ} \mathrm{C}$ (Krishnan et al., 2005).

\section{Choice bioassays}

Larval feeding deterrence. Previous studies have shown feeding arrestant and deterrent effects of 1,8-cineole on neonate larvae of the codling moth when applied at 100 and $300 \mathrm{mg} \mathrm{mL}^{-1}$ (Durden et al., 2009; 2011). In 2010 and 2011, larval feeding deterrence bioassays were conducted to test whether an improved effect can be obtained with the combined application of 1,8-cineole and $\alpha$-terpinyl acetate in microcapsules.

Uninfested and unripe 'Granny Smith' apples, which were about $3 \mathrm{~cm}$ in diameter, were used for whole-fruit choice assays (Pszczolkowski and Brown, 2005). Apples were treated only with $100 \mathrm{mg} \mathrm{mL}^{-1}$ solution of MEC-E based on the previous findings of Durden et al. (2009). On the other hand, two different doses containing 50 and 100 $\mathrm{mg} \mathrm{mL}^{-1}$ solution of MEC-C were sprayed on apples. Apples treated with distilled water were used as a control. They were allowed to air dry after treatments.

For each dose, a pair of apples, one MEC-C-treated and one water-treated, was placed $1 \mathrm{~cm}$ apart in a $70 \mathrm{~mm}$ diameter Pyrex glass crystallizing dish. One neonate larva was gently placed in the middle of the distance between the fruits. A total of 25 neonate larvae were tested individually for each dose for $24 \mathrm{~h}$. The same testing process was followed for evaluating the efficacy of MEC-E treatment. The entire assembly was placed in a semi-translucent polypropylene container and covered with a transparent lid so that an airflow 
that could bias the results of the assay can be avoided. The test bench and feeding arenas were illuminated by fluorescent tubes and positioned in a way that luminosity (460-480 1x) was constant for all tests (Durden et al., 2008).

Feeding deterrence index (DI) was calculated using the following formula developed by Jones (1952):

$\mathrm{DI}=[1-($ Treatment $/$ Control treatment $)] \times 100$

Distilled water was used as a control treatment in calculations.

Oviposition deterrent activity. A plastic vial $(4 \times 6.5 \mathrm{~cm})$, whose bottom was removed and replaced by a cap, was used as a mating chamber for moths emerging from female and male pupae. Emerging moths were provided with a cotton roll soaked in aqueous $15 \%$ raw honey in a small glass inserted through the cover (Wenninger and Landolt, 2011). Fine muslin held tight by a plastic ring about $40 \mathrm{~mm}$ diameter was used to cover the top of the mating chamber. Following female emergence, two 24-h old male moths were transferred to a mating chamber containing a female for $24 \mathrm{~h}$.

In each year, a total of 25 females were used individually for each dose tested in the oviposition bioassay. Only one dose of MEC-E (100 $\left.\mathrm{mg} \mathrm{mL}^{-1}\right)$ and two different doses (50 and $100 \mathrm{mg} \mathrm{mL}^{-1}$ ) of MEC-C were sprayed on fruits inside separate beakers $(50 \mathrm{~mL})$. After drying, the beakers were turned over for an easy collection of the eggs, and one female was put into each beaker. The opening of the beakers was covered with fine muslin. The beakers were then incubated in a growth chamber at $25^{\circ} \mathrm{C}$ and $70 \% \mathrm{RH}$ under $16: 8 \mathrm{~h}$ photoperiod. After $24 \mathrm{~h}$, the female was removed from each beaker, and the number of eggs was counted under a binocular microscope.

\section{Field experiments}

Orchard block layout. Field trials were conducted between 2010 and 2011 at two apple orchards, namely Deydinler $\left(40.03^{\circ} \mathrm{N}, 29.53^{\prime} \mathrm{E}\right)$ and Supurtu $\left(40.07^{\circ} \mathrm{N}, 29.62^{\prime} \mathrm{E}\right)$, located in Inegol town, Bursa, northwestern Turkey. Each orchard was 4-ha in size.

Test orchards consisted of interplanted 'Fuji' and 'Granny Smith' apple trees. Semi-dwarf trees were trained as a slender spindle on 'M.9' rootstock at spacing of $3 \times 5 \mathrm{~m}$. Ten-yearold 'Fuji' trees were about $4 \mathrm{~m}$ in height, whereas 15 -yr old 'Granny Smith' trees averaged $6 \mathrm{~m}$.
Abandoned orchards, each 0.5 ha in size, comprised 30-yr-old 'Golden Delicious' trees grafted on 'MM 106'. Abandoned treatments were located approximately 1-2 km from the study sites because commercial growers did not allow only water-treated controls in the test orchards. On the other hand, most codling moth males can move up to $1 \mathrm{~km}$ (Tyson et al., 2007).

Treatments. Two apple orchards were divided into four 1 ha blocks and sprayed with the following treatments (Table 1): MEC-E at $100 \mathrm{~g} \mathrm{~L}^{-1}$, MEC-C at $50 \mathrm{~g} \mathrm{~L}^{-1}$, MEC-C at $100 \mathrm{~g} \mathrm{~L}^{-1}$, and MEC-pyrethrin at $15 \mathrm{~mL} \mathrm{~L}^{-1}$ (PT 170 X-CLUDE, Whitmire Micro-Gen Research Laboratories, St. Louis, Missouri, USA).

Unpruned abandoned orchards were used as negative controls. They were treated with water only. These orchards were not sprayed with pesticides in the last $5 \mathrm{yr}$.

In Northwestern Turkey, there are two generations of codling moth each year (Kovanci et al., 2010). In order to manage codling moth populations, a total of four applications, two against first generation and two against secondgeneration codling moth, were made at 2-wk intervals for all treatments. Sprays were applied on 29 May and 12 June for the first-generation flight and repeated on 26 July and 9 August for the second-generation flight in 2010. In 2011, spray treatments were made on 8 and 22 June against first generation and treatments were sprayed again to control second generation on 1 and 15 August.

All treatments were applied in $12 \mathrm{~L}$ water ha-1 using a truck-mounted low volume sprayer (Ag-Mister LV8, Curtis Dyna-Fog, Westfield, Indiana, USA) with four multi-mist nozzles turned on. The nozzles delivered a total spray volume of $0.8 \mathrm{~L} \mathrm{~min}^{-1}$ at $200 \mathrm{kPa}$ with a travelling speed of $8 \mathrm{~km} \mathrm{~h}^{-1}$.

In insecticide-treated blocks, a total of four insecticide applications were made during the whole trial period. These blocks were used as positive controls and treated with a botanical insecticide, which contains 1.1\% MECpyrethrin from Tanacetum cinerariifolium (Trevir.) Sch. Bip. plus $2.2 \%$ technical piperonyl butoxide and $3.7 \%$ N-octyl bicycloheptene dicarboximide.

Monitoring. For weekly monitoring of codling moth populations in each treatment, we used two plastic Ajar traps (USDA, Wapato, Washington, USA) baited with both

Table 1. Description of orchard sites and treatments in Deydinler and Supurtu villages of Inegol town, Bursa, Turkey, in 2010 and 2011.

\begin{tabular}{|c|c|c|c|c|c|}
\hline Location & Orchard & Apple Cultivar & Block size & Treatment & Dose \\
\hline \multirow{5}{*}{$\begin{array}{l}\text { Deydinler } \\
\left(40.03^{\circ} \mathrm{N}, 29.53^{\prime} \mathrm{E}\right) \\
\text { Supurtu } \\
\left(40.07^{\circ} \mathrm{N}, 29.62^{\prime} \mathrm{E}\right)\end{array}$} & Conventional & $\begin{array}{c}\text { 'Fuji' } \\
\text { 'Granny Smith' }\end{array}$ & 1 ha & Microencapsulated eucalyptol (MEC-E) & $100 \mathrm{~g} \mathrm{~L}^{-1}$ \\
\hline & Conventional & $\begin{array}{c}\text { 'Fuji' } \\
\text { 'Granny Smith' }\end{array}$ & 1 ha & Microencapsulated cardamom oleoresin (MEC-C) & $50 \mathrm{~g} \mathrm{~L}^{-1}$ \\
\hline & Conventional & $\begin{array}{c}\text { 'Fuji' } \\
\text { 'Granny Smith' }\end{array}$ & 1 ha & Microencapsulated cardamom oleoresin (MEC-C) & $100 \mathrm{~g} \mathrm{~L}^{-1}$ \\
\hline & Conventional & $\begin{array}{c}\text { 'Fuji' } \\
\text { 'Granny Smith' }\end{array}$ & 1 ha & Microencapsulated-pyrethrin (MEC-pyrethrin) & $15 \mathrm{~mL} \mathrm{~L}^{-1}$ \\
\hline & Abandoned, $5 \mathrm{yr}$, unpruned, $\sim 1 \mathrm{~km}$ & 'Golden Delicious' & 0.5 ha & Water only & $12 \mathrm{~L} \mathrm{ha}^{-1}$ \\
\hline
\end{tabular}


DA-combo lure and food attractant containing $350 \mathrm{~mL}$ of $0.05 \%$ terpinyl acetate plus $10 \%$ brown sugar solution (Cichon et al., 2013). The DA-combo lure is composed of pear ester kairomone, ethyl (E,Z)-2,4-decadienoate, and codling moth pheromone, $(E, E)-8,10$-dodecadien-1-ol. A complete description of the terpinyl acetate bait trap is given in Cichon et al. (2013). Traps were hung at $50 \mathrm{~m}$ apart in the upper third of the canopy, and the liquid solution was changed once a week.

Traps baited with DA-combo lure and terpinyl acetate can catch both sexes of codling moth (Barros et al., 2013). The treatment efficacy was evaluated by comparing male and female moth catch in deterrent- and insecticide-treated blocks. Trapped moths were put in vials and returned to the laboratory, where the sex of each moth was determined. The presence of a spermatophore in the bursa copulatrix was checked by dissecting the abdomens of females to determine their mating status.

Damage assessment. Moth catches alone may fail to provide an accurate estimation of codling moth damage. Therefore, fruit damage assessments are necessary to determine the effectiveness of treatments. In each treatment, damage assessment was made twice during a season, the first during July (the mid-season assessment) and the second during September (the pre-harvest assessment). For each assessment, a total of 1000 fruits (10 fruits per tree $\times 10$ trees per treatment $\times 5$ treatments per location $\times 2$ locations) were randomly picked to assess external and internal injury. The injury was categorized into two groups, with "stings" indicating superficial damage being $<6 \mathrm{~mm}$ deep, and "live worm" for larva collected alive during the sampling (Kovanci, 2015).

\section{Data analysis}

Exact Fisher's test $(\alpha=0.05)$ was used for evaluation of larval fruit preference in choice bioassays. The null hypothesis that codling moth neonates do not discriminate between apples treated either with MEC-E or MEC-C and those treated with distilled water was tested. Data for oviposition deterrence were subjected to one-way ANOVA ( $\mathrm{p}<0.05)$.

Male and female moth catches in Ajar traps were compared among treatments using ANOVA. Tukey's HSD post-hoc test was used to identify whether there were any significant interaction effects. The mean percentage fruit damage was transformed using arcsine square root and data were analyzed by ANOVA.

\section{RESULTS}

\section{Choice bioassays}

Larval feeding deterrence. In larval feeding bioassays, MEC-E exhibited the lowest feeding deterrent activity
(33\%) while MEC-C at $100 \mathrm{mg} \mathrm{mL}^{-1}$ had the highest $(91 \%)$ according to a comparative analysis of $2 \mathrm{yr}$ data (Table 2). Infested fruits had abraded epidermis, larval frass and stings as a sign of feeding.

\section{Oviposition deterrent activity}

Codling moth females laid an average of 44-50 eggs on water-treated fruits. The effect of MEC-C treatments on the number of eggs laid by codling moth females is shown in Table 3.

Significantly fewer eggs were laid on apples treated with $100 \mathrm{mg} \mathrm{mL}^{-1}$ of MEC-C compared with other treatments in both years $(\mathrm{F}=61.22$, d.f. $=3,96, \mathrm{P}<0.01$ for 2010 ; $\mathrm{F}=$ 70.81 , d.f. $=3,96, \mathrm{P}<0.01$ for 2011).

\section{Field experiments}

Flight monitoring. Table 4 shows the mean male and female moth catches for all treatments in 2010 and 2011. A total of 4329 male and 2063 female moths were caught in Ajar traps during a 2-yr study period. There was a significant treatment

Table 2. Effects of microencapsulated eucalyptol (MEC-C) and microencapsulated cardamom oleoresin (MEC-E) on apple feeding by neonate larvae of Cydia pomonella in 2010 and 2011.

\begin{tabular}{|c|c|c|c|c|c|}
\hline \multirow[b]{2}{*}{ Year } & \multirow[b]{2}{*}{ Treatment } & \multirow[b]{2}{*}{ Concentration } & \multicolumn{3}{|c|}{$\mathrm{Nr}$ of neonates feeding } \\
\hline & & & $\begin{array}{c}\text { Treated } \\
\text { fruit }\end{array}$ & $\begin{array}{c}\text { Control } \\
\text { fruit }\end{array}$ & $\begin{array}{c}\text { Deterrence } \\
\text { index }\end{array}$ \\
\hline & & $\mathrm{mg} \mathrm{mL}^{-1}$ & & & $\%$ \\
\hline \multirow[t]{4}{*}{2010} & Water control $^{1}$ & 0 & 15 & 10 & Not deterrent \\
\hline & MEC-E & 100 & 9 & 15 & 40.00 \\
\hline & MEC-C & 50 & $7 *$ & 16 & 56.25 \\
\hline & MEC-C & 100 & $3 * *$ & 21 & 85.70 \\
\hline \multirow[t]{4}{*}{2011} & Water control ${ }^{*}$ & 0 & 13 & 12 & Not deterrent \\
\hline & MEC-E & 100 & 10 & 15 & 33.33 \\
\hline & MEC-C & 50 & $8 *$ & 17 & 52.94 \\
\hline & MEC-C & 100 & $2 * *$ & 23 & 91.30 \\
\hline
\end{tabular}

${ }^{1}$ Fruits treated with distilled water served as a control except the water control treatment in which the larval host preference between untreated and distilled water treated apples was compared.

${ }^{*} \mathrm{P}<0.05$

${ }^{* *} \mathrm{P}<0.01$ in Fisher's exact test.

Table 3. Effects of microencapsulated eucalyptol (MEC-E) and microencapsulated cardamom oleoresin (MEC-C) on the mean \pm SEM number of eggs laid by Cydia pomonella females in $\mathbf{2 0 1 0}$ and 2011.

\begin{tabular}{|c|c|c|c|c|}
\hline Year & Treatment & Concentration & $\begin{array}{l}\text { Mean } \\
\text { number of } \\
\text { laid eggs }\end{array}$ & $\begin{array}{l}\text { Deterrence } \\
\text { index }\end{array}$ \\
\hline & & $\mathrm{mg} \mathrm{mL}^{-1}$ & & $\%$ \\
\hline \multirow[t]{4}{*}{2010} & Water control ${ }^{1}$ & 0 & $44.40 \pm 2.56 \mathrm{a}$ & - \\
\hline & MEC-E & 100 & $24.84 \pm 2.20 b$ & 44.00 \\
\hline & MEC-C & 50 & $17.32 \pm 1.67 \mathrm{c}$ & 61.00 \\
\hline & MEC-C & 100 & $8.34 \pm 0.97 d$ & 81.20 \\
\hline \multirow[t]{4}{*}{2011} & Water control $^{1}$ & 0 & $50.20 \pm 3.20 \mathrm{a}$ & - \\
\hline & MEC-E & 100 & $28.88 \pm 2.06 b$ & 42.40 \\
\hline & MEC-C & 50 & $18.56 \pm 1.59 \mathrm{c}$ & 63.00 \\
\hline & MEC-C & 100 & $8.60 \pm 0.92 d$ & 83.80 \\
\hline
\end{tabular}

${ }^{1}$ Fruits treated with distilled water served as a control. 
Table 4. Mean cumulative codling moth captures $( \pm$ SEM) in Ajar traps in abandoned orchards versus those treated with microencapsulated eucalyptol (MEC-E) and MEC-cardamom oleoresin (MEC-C) and microencapsulated pyrethrin in Bursa, Turkey, in 2010 and 2011.

\begin{tabular}{|c|c|c|c|c|}
\hline \multirow[b]{2}{*}{ Year } & \multirow[b]{2}{*}{ Treatment } & \multicolumn{3}{|c|}{$\begin{array}{l}\text { Mean cumulative moths per } \\
\text { trap per week }^{1}\end{array}$} \\
\hline & & Male & Female & Total \\
\hline \multirow[t]{5}{*}{2010} & MEC-E at $100 \mathrm{~g} \mathrm{~L}^{-1}$ & $23.9(2.7) \mathrm{a}$ & $10.2(1.4) \mathrm{a}$ & $34.1(2.1) \mathrm{a}$ \\
\hline & MEC-C at $50 \mathrm{~g} \mathrm{~L}^{-1}$ & $11.2(3.8) \mathrm{b}$ & $7.1(1.0) \mathrm{b}$ & $18.3(1.5) \mathrm{b}$ \\
\hline & MEC-C at $100 \mathrm{~g} \mathrm{~L}^{-1}$ & $4.4(1.9) \mathrm{bc}$ & $2.7(0.8) \mathrm{c}$ & $7.1(1.3) \mathrm{c}$ \\
\hline & MEC-pyrethrin at $15 \mathrm{~mL} \mathrm{~L}^{-1}$ & $3.3(1.2) \mathrm{c}$ & $1.6(0.5) \mathrm{c}$ & $4.9(1.0) \mathrm{c}$ \\
\hline & Abandoned (Water-treated) & $28.5(3.6) \mathrm{a}$ & $12.7(1.1) \mathrm{a}$ & $41.2(2.6) \mathrm{a}$ \\
\hline \multirow[t]{5}{*}{2011} & MEC-E at $100 \mathrm{~g} \mathrm{~L}^{-1}$ & $28.8(3.1) \mathrm{a}$ & $16.8(2.9) \mathrm{a}$ & $45.6(3.0) \mathrm{a}$ \\
\hline & MEC-C at $50 \mathrm{~g} \mathrm{~L}^{-1}$ & $13.6(2.0) \mathrm{b}$ & $3.3(1.2) \mathrm{b}$ & $16.9(1.6) \mathrm{b}$ \\
\hline & MEC-C at $100 \mathrm{~g} \mathrm{~L}^{-1}$ & $3.8(1.3) \mathrm{c}$ & $1.5(0.4) b$ & $5.3(0.8) \mathrm{c}$ \\
\hline & MEC-pyrethrin at $15 \mathrm{~mL} \mathrm{~L}^{-1}$ & $3.1(0.8) \mathrm{c}$ & $1.2(0.2) b$ & $4.3(0.5) \mathrm{c}$ \\
\hline & Abandoned (Water-treated) & $22.6(2.8) \mathrm{a}$ & $15.0(2.5) \mathrm{a}$ & $37.6(2.8) \mathrm{a}$ \\
\hline \multirow[t]{5}{*}{ Pooled } & MEC-E at $100 \mathrm{~g} \mathrm{~L}^{-1}$ & $26.3(3.4) \mathrm{a}$ & $13.5(2.1) \mathrm{a}$ & $39.8(2.3) \mathrm{a}$ \\
\hline & MEC-C at $50 \mathrm{~g} \mathrm{~L}^{-1}$ & $12.4(1.9) \mathrm{b}$ & $5.2(1.5) \mathrm{b}$ & $17.6(1.5) \mathrm{b}$ \\
\hline & MEC-C at $100 \mathrm{~g} \mathrm{~L}^{-1}$ & $4.1(1.0) \mathrm{c}$ & $1.9(0.8) \mathrm{c}$ & $6.0(0.8) \mathrm{c}$ \\
\hline & MEC-pyrethrin at $15 \mathrm{~mL} \mathrm{~L}^{-1}$ & $3.2(1.3) \mathrm{c}$ & $1.5(0.6) \mathrm{c}$ & $4.7(1.0) \mathrm{c}$ \\
\hline & Abandoned (Water-treated) & $25.6(3.2) \mathrm{a}$ & $13.9(1.8) \mathrm{a}$ & $39.4(2.7) \mathrm{a}$ \\
\hline
\end{tabular}

${ }^{1}$ Within the same column, means followed by the same letter do not differ significantly by Tukey's HSD post-hoc test for each year $(\mathrm{P}<0.05)$.

effect on moth catches $(\mathrm{F}=35.46$, d.f. $=4,315, \mathrm{P}<0.01)$. Male and female moth catches were significantly higher in the abandoned and MEC-E blocks than those treated with MEC-C and MEC-pyrethrin. However, moth catches per trap were not significantly different between years and orchards $(\mathrm{F}=0.09$, d.f. $=1,318, \mathrm{P}=0.76 ; \mathrm{F}=0.52$, d.f. $=1,318, \mathrm{P}$ $=0.47$ ).

Treatment effects did not significantly vary over weeks and generations $(\mathrm{F}=0.39$; d.f. $=12,300 ; \mathrm{P}=0.96 ; \mathrm{F}=2.41$, d.f. $=1,318, \mathrm{P}=0.12)$. However, when interaction effects of generation, week and treatment were analyzed, significant differences were detected in the counts of moths captured in each treatment (Table 5, F = 4.93, d.f. $=39,280, \mathrm{P}<0.01$ ).
Based on pooled data, females represented about 30\%$40 \%$ of the total moth catch (Table 4), with the percentage of mating remained below or equal to $50 \%$ in all treatments except the distant abandoned blocks (Table 6).

Damage assessment. Fruit injury by codling moth larvae at mid-season and pre-harvest, respectively is reported in Table 7. The mean percentage of fruits with $C$. pomonella larvae and stings did not significantly differ between the mid-season and pre-harvest assessment $(\mathrm{F}=2.29$, d.f. $=1$, $3998, \mathrm{P}=0.13$ for larvae; $\mathrm{F}=1.27$, d.f. $=1,3998, \mathrm{P}=0.25$ for stings). Among treatments, the highest incidence of mean larval counts and stings occurred in the abandoned blocks followed by MEC-E treated blocks $(\mathrm{F}=102.96$, d.f. $=4$, $3995, \mathrm{P}<0.01$ for larvae; $\mathrm{F}=76.17$, d.f. $=4,3995, \mathrm{P}<0.01$ for stings).

Table 6. Comparison of the mating status of female moths ( \pm SEM) caught in Ajar traps placed in abandoned orchards versus those treated with microencapsulated cardamom oleoresin (MEC-C), microencapsulated eucalyptol (MEC-E) and microencapsulated pyrethrin in Bursa, Turkey in 2010 and 2011.

\begin{tabular}{|c|c|c|c|c|}
\hline \multirow[b]{2}{*}{ Year } & \multirow[b]{2}{*}{ Treatment $^{1}$} & \multicolumn{3}{|c|}{$\begin{array}{l}\text { Mean cumulative moths per } \\
\text { trap per week }\end{array}$} \\
\hline & & Mated & Total & $\begin{array}{l}\text { Percentage } \\
\text { mated }(\%)\end{array}$ \\
\hline \multirow[t]{5}{*}{2010} & MEC-E at $100 \mathrm{~g} \mathrm{~L}^{-1}$ & $4.3(1.2) \mathrm{b}$ & $10.2(1.4) \mathrm{ab}$ & 42.1 \\
\hline & $\mathrm{MEC}-\mathrm{C}$ at $50 \mathrm{~g} \mathrm{~L}^{-1}$ & $2.8(0.8) \mathrm{b}$ & $7.1(1.0) b c$ & 39.4 \\
\hline & $\mathrm{MEC}-\mathrm{C}$ at $100 \mathrm{~g} \mathrm{~L}^{-1}$ & $1.1(1.0) \mathrm{b}$ & $2.7(0.8) \mathrm{cd}$ & 40.7 \\
\hline & MEC-pyrethrin at $15 \mathrm{~mL} \mathrm{~L}^{-1}$ & $0.8(0.5) b$ & $1.6(0.9) \mathrm{d}$ & 50.0 \\
\hline & Abandoned (Water-treated) & $8.9(2.0) \mathrm{a}$ & $12.8(1.1) \mathrm{a}$ & 70.0 \\
\hline \multirow[t]{5}{*}{2011} & MEC-E at $100 \mathrm{~g} \mathrm{~L}^{-1}$ & $7.3(1.7) b$ & 16.8 (2.9)a & 43.4 \\
\hline & MEC-C at $50 \mathrm{~g} \mathrm{~L}^{-1}$ & $1.3(0.6) \mathrm{c}$ & $3.3(1.2) \mathrm{b}$ & 39.3 \\
\hline & $\mathrm{MEC}-\mathrm{C}$ at $100 \mathrm{~g} \mathrm{~L}^{-1}$ & $0.6(0.4) \mathrm{c}$ & $1.5(0.4) b$ & 40.0 \\
\hline & MEC-pyrethrin at $15 \mathrm{~mL} \mathrm{~L}^{-1}$ & $0.6(0.2) \mathrm{c}$ & $1.2(0.2) \mathrm{b}$ & 50.0 \\
\hline & Abandoned (Water-treated) & $11.4(1.2) \mathrm{a}$ & $15.0(2.5) \mathrm{a}$ & 76.0 \\
\hline
\end{tabular}

${ }^{1}$ All treatments were re-applied at 2 wk intervals. Within the same column, means followed by the same letter do not differ significantly by Tukey's HSD post-hoc test $(P<0.05)$.

Table 5. Mean codling moth captures $( \pm$ SEM) in Ajar traps over a 4 wk monitoring period during first and second generation flight in abandoned orchards versus those treated with microencapsulated cardamom oleoresin (MEC-C), microencapsulated eucalyptol (MEC-E) and microencapsulated pyrethrin averaged over two application periods in Bursa, Turkey, in 2010 and 2011.

\begin{tabular}{|c|c|c|c|c|c|}
\hline \multirow[b]{2}{*}{ Generation } & \multirow[b]{2}{*}{ Treatment $^{1}$} & \multicolumn{4}{|c|}{ Week $^{2}$} \\
\hline & & 1 & 2 & 3 & 4 \\
\hline \multirow[t]{5}{*}{1} & MEC-E at $100 \mathrm{~g} \mathrm{~L}^{-1}$ & $30.3(3.4) \mathrm{a}$ & $29.9(2.2) b$ & $55.0(4.0) \mathrm{a}$ & $62.4(5.5) \mathrm{a}$ \\
\hline & MEC-C at $50 \mathrm{~g} \mathrm{~L}^{-1}$ & $12.5(1.8) \mathrm{b}$ & $12.8(2.0) \mathrm{c}$ & $19.8(1.6) \mathrm{c}$ & $21.5(2.2) b$ \\
\hline & MEC-C at $100 \mathrm{~g} \mathrm{~L}^{-1}$ & $3.5(1.3) \mathrm{b}$ & $6.3(1.2) \mathrm{c}$ & $7.9(1.8) \mathrm{cd}$ & $10.1(1.0) \mathrm{b}$ \\
\hline & MEC-pyrethrin at $15 \mathrm{~mL} \mathrm{~L}^{-1}$ & $3.3(0.9) \mathrm{b}$ & $5.8(1.4) \mathrm{c}$ & 6.8 (1.9)d & $6.9(1.3) b$ \\
\hline & Abandoned (Water-treated) & $43.1(2.4) \mathrm{a}$ & $40.6(1.5) \mathrm{a}$ & $37.0(1.2) \mathrm{b}$ & $64.3(3.0) \mathrm{a}$ \\
\hline \multirow[t]{5}{*}{2} & MEC-E at $100 \mathrm{~g} \mathrm{~L}^{-1}$ & $43.4(3.1) \mathrm{a}$ & $50.1(4.3) \mathrm{a}$ & 20.8 (2.5)ab & $31.0(2.8) \mathrm{a}$ \\
\hline & $\mathrm{MEC}-\mathrm{C}$ at $50 \mathrm{~g} \mathrm{~L}^{-1}$ & $10.3(1.4) \mathrm{b}$ & $12.4(1.7) \mathrm{bc}$ & 17.9 (2.3)abc & $30.6(2.6) a$ \\
\hline & MEC-C at $100 \mathrm{~g} \mathrm{~L}^{-1}$ & $3.9(1.1) \mathrm{b}$ & $3.4(0.9) \mathrm{c}$ & $7.4(3.7) b c$ & $10.0(2.9) \mathrm{b}$ \\
\hline & MEC-pyrethrin at $15 \mathrm{~mL} \mathrm{~L}^{-1}$ & $2.1(0.5) b$ & $2.4(1.2) \mathrm{c}$ & $2.9(0.8) \mathrm{c}$ & $4.6(2.3) b$ \\
\hline & Abandoned (Water-treated) & $39.1(2.0) \mathrm{a}$ & $23.3(2.4) b$ & $33.1(1.8) \mathrm{a}$ & $34.6(1.9) \mathrm{a}$ \\
\hline \multirow[t]{5}{*}{ Pooled data } & MEC-E at $100 \mathrm{~g} \mathrm{~L}^{-1}$ & $36.8(2.4) \mathrm{a}$ & $40.0(1.3) \mathrm{a}$ & $36.4(2.2) \mathrm{a}$ & $46.7(1.5) \mathrm{a}$ \\
\hline & $\mathrm{MEC}-\mathrm{C}$ at $50 \mathrm{~g} \mathrm{~L}^{-1}$ & $11.4(1.6) \mathrm{b}$ & $12.6(1.1) \mathrm{b}$ & $20.3(2.0) b$ & $26.0(1.7) b$ \\
\hline & MEC-C at $100 \mathrm{~g} \mathrm{~L}^{-1}$ & $3.7(0.9) \mathrm{b}$ & $4.8(0.8) \mathrm{b}$ & $7.6(1.3) \mathrm{c}$ & $8.4(1.0) \mathrm{c}$ \\
\hline & MEC-pyrethrin at $15 \mathrm{~mL} \mathrm{~L}^{-1}$ & $2.7(0.5) b$ & $4.1(0.9) \mathrm{b}$ & $4.8(0.6) \mathrm{c}$ & $7.4(1.6) \mathrm{c}$ \\
\hline & Abandoned (Water-treated) & $41.1(2.2) \mathrm{a}$ & $32.0(2.0) \mathrm{a}$ & $35.0(1.5) \mathrm{a}$ & $49.4(2.5) \mathrm{a}$ \\
\hline
\end{tabular}

${ }^{1}$ All treatments were re-applied at 2 wk intervals. Sprays were applied on 29 May and 12 June for the first generation flight and repeated on 26 July and 9 August for the second generation flight in 2010. In 2011, spray treatments were made on 8 and 22 June against first generation and treatments were sprayed again to control second generation on 1 and 15 August.

${ }^{2}$ Within the same column, means followed by the same small letter do not differ significantly according to Tukey’s HSD post-hoc test (P < 0.05 ). 
Table 7. Mean percentage fruit damage ( \pm SEM) by codling moth larvae at mid-season and pre-harvest in abandoned orchards versus those treated with microencapsulated cardamom oleoresin (MEC-C), microencapsulated eucalyptol (MEC-E) and microencapsulated pyrethrin in Bursa, Turkey, in 2010 and 2011.

\begin{tabular}{|c|c|c|c|c|c|}
\hline \multirow[b]{3}{*}{ Year } & \multirow[b]{3}{*}{ Treatment } & \multicolumn{4}{|c|}{ Mean $\%$ fruit injury ${ }^{1}$} \\
\hline & & \multicolumn{2}{|c|}{ Mid-season } & \multicolumn{2}{|c|}{ Pre-harvest } \\
\hline & & Stings & Live worm & Stings & Live worm \\
\hline \multirow[t]{5}{*}{2010} & MEC-E at $100 \mathrm{~g} \mathrm{~L}^{-1}$ & $12.8(2.1) \mathrm{b}$ & $9.9(2.7) \mathrm{b}$ & $11.2(1.9) \mathrm{b}$ & $13.9(2.7) \mathrm{b}$ \\
\hline & MEC-C at $50 \mathrm{~g} \mathrm{~L}^{-1}$ & $3.5(0.8) \mathrm{c}$ & $4.4(1.1) \mathrm{b}$ & $3.2(1.0) \mathrm{bc}$ & $6.0(2.0) \mathrm{bc}$ \\
\hline & MEC-C at $100 \mathrm{~g} \mathrm{~L}^{-1}$ & $3.2(1.1) \mathrm{c}$ & $1.9(0.7) \mathrm{b}$ & $2.6(1.3) \mathrm{bc}$ & $2.3(1.5) \mathrm{c}$ \\
\hline & MEC-pyrethrin at $15 \mathrm{~mL} \mathrm{~L}^{-1}$ & $0.6(0.3) \mathrm{c}$ & $0.3(0.2) \mathrm{b}$ & $0.6(0.2) \mathrm{c}$ & $0.1(0.1) \mathrm{c}$ \\
\hline & Abandoned (Water-treated) & $21.9(2.7) \mathrm{a}$ & $35.9(2.2) \mathrm{a}$ & $26.4(3.1) \mathrm{a}$ & $49.8(1.9) \mathrm{a}$ \\
\hline \multirow[t]{5}{*}{2011} & MEC-E at $100 \mathrm{~g} \mathrm{~L}^{-1}$ & $16.3(3.3) \mathrm{b}$ & $19.6(3.2) \mathrm{b}$ & $21.2(3.0) \mathrm{b}$ & $24.1(4.2) \mathrm{b}$ \\
\hline & MEC-C at $50 \mathrm{~g} \mathrm{~L}^{-1}$ & $6.1(1.7) \mathrm{c}$ & $3.5(1.9) \mathrm{c}$ & $6.2(2.1) \mathrm{c}$ & $9.7(2.5) \mathrm{bc}$ \\
\hline & MEC-C at $100 \mathrm{~g} \mathrm{~L}^{-1}$ & $2.5(1.2) \mathrm{c}$ & $1.1(0.7) \mathrm{c}$ & $2.2(1.4) \mathrm{c}$ & $1.8(0.8) \mathrm{c}$ \\
\hline & MEC-pyrethrin at $15 \mathrm{~mL} \mathrm{~L}^{-1}$ & $1.8(1.0) \mathrm{c}$ & $0.4(0.1) \mathrm{c}$ & $1.5(0.9) \mathrm{c}$ & $0.3(0.1) \mathrm{c}$ \\
\hline & Abandoned (Water-treated) & $25.2(1.9) \mathrm{a}$ & $40.7(4.1) \mathrm{a}$ & $35.0(2.3) \mathrm{a}$ & $78.6(3.5) \mathrm{a}$ \\
\hline
\end{tabular}

${ }^{1}$ For each year, column means followed by a different letter were significantly different according to Tukey's HSD post-hoc test $(P<0.05)$. Data were analyzed using arcsine square root, but data shown are back transformations.

\section{DISCUSSION}

Results of laboratory and field studies demonstrate that MEC-C treatments effectively reduced oviposition by codling moth females, as well as fruit infestation by neonate larvae in a dose-dependent manner (Tables 2-7). To my knowledge, this is the first report on the oviposition and feeding deterrent effects of the cardamom oleoresin against codling moth.

There is a lack of studies on the antifeedant and oviposition deterrent properties of spice oleoresins against insect pests. In contrast, some spice essential oils have already been shown to protect fruit from attack by codling moth larvae in previous studies. Suomi et al. (1986) identified the oils of absinthe wormwood (Artemisia absinthium L.), garlic (Allium sativum L.), and tansy (Tanacetum vulgare L.) as effective repellents and arrestants against neonate codling moth larvae. Landolt et al. (1999) added that these young larvae can also be repelled or arrested by the spicy essential oils derived from lavender (Lavandula officinalis Chaix), patchouly (Pogostemon cablin [Blanco] Benth.), pennyroyal (Mentha pulegium L.), and rue (Ruta graveolens L.) There appears to be no commercially available microencapsulation based products of these essential oils yet, but they are potentially good candidates for alternative control of codling moth in future studies.

Most spicy essential oils are composed of complex mixtures of plant secondary metabolites including alkaloids, phenols, mono- and sesquiterpenoid compounds (Isman, 2006). Hence, more research needs to be done on the isolation and identification of the chemical constituents of essential oils that discourage pests from infesting the fruit. The present study confirms previous findings of Landolt et al. (1999) and contributes additional evidence that 1,8-cineole has a repellent effect on codling moth neonate larvae. Laboratory bioassays also confirmed feeding deterrent properties of 1,8-cineole against neonate larvae of codling moth, corroborating with the findings of Durden et al. (2009; 2011).
Nevertheless, MEC-E treatments had a lower feeding deterrence index (33-40\%) for codling moth neonate larvae than that of 1,8-cineole extracts derived from Artemisia апnиа L. plants (56.5\%) based on the results of Durden et al. (2011). In spite of reporting a similar feeding deterrence index (50\%), Tripathi et al. (2001) attributed the toxicity of A. аппиа extracts against Tribolium castaneum larvae solely to 1,8 -cineole. This secondary metabolite has been thought to play a major role in defenses against herbivores, but the results of the current study suggest that 1,8-cineole has either a more minimal or more complex involvement in plant defense when compared to other metabolites such as artemisinin (Durden et al., 2011).

When applied to plants, inhibitory chemicals may cause insects to stop feeding by stimulating deterrent cells or by blocking the perception of gustatory signals (Isman, 2002). Field studies revealed that there was significantly less damage from larval feeding in the MEC-E blocks compared with the abandoned blocks despite high moth catches in both treatments (Tables 4 and 7). Significant differences in fruit damage levels between treatments under similar codling moth pressure could be due to the feeding deterrent activity of MEC-E treatment against larvae.

In Lepidoptera, it is particularly important for females to select a suitable site to lay their eggs since it is difficult for neonate larvae to forage for their preferred host plants. Nonhost plants emit chemicals that deter female insects from oviposit on foliage or directly on fruit (Liu et al., 2006). Tarsal and ovipositor sensilla of female moths can be used as a chemoreceptor for detecting host and non-host plant compounds (Yi et al., 2014).

Both MEC-C and MEC-E treatments had a negative effect on the egg-laying behavior of female codling moths (Table 3). However, females had attempted oviposition much more often on fruits treated with MEC-E than those treated with MEC-C. Increasing attempts of oviposition on fruits by females over time in MEC-E treatments suggest that prolonged exposure may either produce habituation in females or change their oviposition preferences as previously 
pointed out by Akhtar and Isman (2003). Conversely, Koul et al. (2013) identified the strong oviposition deterrent and ovicidal properties of eucalyptol (1,8-cineole) against adult females of Helicoverpa armigera (Hübner, 1827), Spodoptera litura (Fabricius, 1775), and C. partellus. Like eucalyptol, cardamom oil has been used successfully to prevent oviposition and hatching of the eggs of various stored product pests (Abbasipour et al., 2011).

In addition to oviposition deterrent activities, volatiles released from non-host plants may interfere with the behavioral response of insects to pheromones and host kairomones. As an inhibitory host compound, 1,8-cineole was shown to modulate the response of Ips typographus (Degeer, 1775) adults by reducing attraction to their pheromone (Binyameen et al., 2014). However, the same disruptive effect of 1,8-cineole could not be produced against codling moth in this study. MEC-E treatments were unable to keep codling moth populations below suggested trap thresholds of 5-10 codling moths per trap per week (Tables 4 and 5). This diversity of dramatically different responses to 1,8-cineole between codling moths and bark beetles could be due to moth's highly specialized pheromone detection system (Binyameen et al., 2012). On the other hand, the proportion of mated female moths still remained below 50\% in MEC-E treated blocks (Table 6). Further studies are needed to investigate the mechanisms underlying the inhibitory effect of non-host plant volatiles on the reproductive success of codling moth.

Generally, the combined effect of binary mixtures of essential oil constituents was found to be greater than that of individual compounds owing to their additive and synergistic effects against lepidopterans (Isman et al., 2008; Singh et al., 2009). For example, the binary mixture of 1,8-cineole with $\alpha$-terpinyl acetate in MEC-C formulation was more deterrent than MEC-E formulation containing 1,8-cineole alone against codling moth larvae and adults. In terms of the synergistic effects of the combination of terpineoids with 1,8-cineole, our findings are similar to those of Singh et al. (2009). These additive and synergistic effects of binary mixtures against lepidopterans could be attributed to their ability to prevent habituation of the olfactory response in the larval and adult stages (Akhtar and Isman, 2003; Koul et al., 2003; 2004; Isman et al., 2008; Singh et al., 2009). For this reason, MEC-spice oleoresins composed of binary mixtures merit further study as potential deterrents or repellents for other lepidopteran pests.

Unfortunately, it was not possible to set up only watertreated controls in the conventional orchards. Apart from the conventional orchards, abandoned orchards within a radius of 1-2 km were included in this study. Apple cultivars differed between conventional and abandoned orchards. Not surprisingly, unpruned and old trees in abandoned orchards produced fewer apple fruits than conventionally managed orchards. In addition to treatment effects, varying cultivar practices, cultivars and habitats in distant orchards may have contributed to the differences in population and damage levels of the codling moth.
It was also evident in the abandoned blocks that Ajar traps were able to catch both sexes of Oriental fruit moth and codling moth adults. In fact, these traps were developed mainly for monitoring Oriental fruit moth, with side effects of the attraction of sugar baits and $\alpha$-terpinyl acetate toward codling moth. However, the addition of combo bait containing pear ester and codling moth pheromone into Ajar traps greatly improved their attractivity and specificity to codling moth.

The use of essential oils in the open field has met with only limited success due to their short residual activity for no longer than $1 \mathrm{wk}$. Unlike the plant essential oils, the high antioxidant content of spice oleoresins allows them to become more persistent in the environment. Furthermore, microencapsulation increases the effectiveness of oleoresin formulation over time by preventing losses of volatile compounds. MEC-C treatments appeared to be effective over a 2 -wk period as no significant differences were detected in moth catches between the first and second week after treatments based on pooled data (Table 5). In line with these results, López et al. (2014) observed a slow release profile of the microencapsulated essential oil, which was derived from Schinus molle L. leaves, over a period of $15 \mathrm{~d}$. Further field testing is required to study the effect of increased spraying interval on the efficacy of MEC-oleoresin treatments.

EcoSMART Technologies (Roswell, Georgia, USA) is currently selling essential oil-based pesticides in more than 10 countries. However, the cost of essential oils relative to their control efficacy is not economically feasible in most cases (van Tol et al., 2007). In contrast, oleoresins can be more cost-effective than essential oils because they are more stable in the environment. Cardamom oleoresin is obtained by the solvent extraction of the dried fruits and seeds of $E$. cardamomum with an average yield of $8 \%-12 \%$, respectively (Weiss, 2002). In other words, about $10 \mathrm{~kg}$ dried seed would be required to produce $1 \mathrm{~kg}$ cardamom oleoresin. Thus, the price of the cardamom oleoresin may be approximately US\$120 kg-1 if the cost of cardamom seed is assumed at US\$12 $\mathrm{kg}^{-1}$ (Nair and Kutty, 2004).

However, microencapsulation technology allows for the low volume application of cardamom oil in smaller quantities compared with direct spraying as pure compounds. The aim of ultra-low volume sprays was to provide a low dose delivery of the microencapsulated products, making use of plant extracts more economically feasible. Low volume sprays have a lower application cost than high volume sprays due to the lower volume of the mix being applied. Besides the cost-effectiveness for the grower, the low volume solution is also effective thanks to the deposition of large microcapsule clumps on the tree canopy (Knight et al., 2008; Kovanci et al., 2010).

\section{CONCLUSIONS}

This study encourages further research into the potential effects of microencapsulated spice oils and oleoresins on other 
pests. Apparently, one compound alone may not be sufficient to control codling moth as in the case of microencapsulated eucalyptol (MEC-E). Despite good oviposition and feeding deterrent effects, high-dose microencapsulated cardamom oleoresin (MEC-C) applications should not be considered a stand-alone treatment for codling moth control. Since fruit injury exceeded the economic damage threshold $(>1 \%)$ at both doses of MEC-C, high dose treatments can only be incorporated into integrated pest management programs as a supplementary tactic to reduce codling moth populations.

\section{ACKNOWLEDGEMENTS}

I am grateful to emeritus professor Uwe Koch for providing codling moth pupae. I also thank Dr. Alan Knight for supplying Ajar traps.

\section{REFERENCES}

Abbasipour, H., M. Mahmoudvand, F. Rastegar, and M.H Hosseinpour. 2011. Fumigant toxicity and oviposition deterrency of the essential oil from cardamom, Elettaria cardamomum, against three stored-product insects. Journal of Insect Science 11:165.

Akhtar, Y., and M.B. Isman. 2003. Larval exposure to oviposition deterrents alters sub-sequent oviposition behavior in generalist, Trichoplusia $n i$ and specialist, Plutella xylostella moths. Journal of Chemical Ecology 29:1853-1870.

Barros, W., A.L. Knight, E. Basoalto, and E. Fuentes-Contreras. 2013. Evaluation of traps and lures for codling moth (Lepidoptera: Tortricidae) in apple orchards. Chilean Journal of Agricultural Research 40:307-315.

Binyameen, M., P. Anderson, R. Ignell, M.A. Seada, B.S. Hansson, and F. Schlyter. 2012. Spatial organization of antennal olfactory sensory neurons in the female Spodoptera littoralis moth: Differences in sensitivity and temporal characteristics. Chemical Senses 37:613-629.

Binyameen, M., J. Jankuvová, M. Blaženec, R. Jakuš, L. Song, F. Schlyter, et al. 2014. Co-localization of insect olfactory sensory cells improves the discrimination of closely separated odour sources. Functional Ecology 28:1216-1223.

Caballero-Gallardo, K., J. Olivero-Verbel, and E.E. Stashenko. 2011. Repellent activity of essential oils and some of their individual constituents against Tribolium castaneum Herbst. Journal of Agricultural and Food Chemistry 59:1690-1696.

Campolo, O., F.V. Romeo, A. Malacrinò, F. Laudani, G. Carpinteri, S. Fabroni, et al. 2014. Effects of inert dusts applied alone and in combination with sweet orange essential oil against Rhyzopertha dominica (Coleoptera: Bostrichidae) and wheat microbial population. Industrial Crops and Products 61:361-369.

Cichon, L., E. Fuentes-Contreras, S. Garrido, J. Lago, W. BarrosParada, E. Basoalto, et al. 2013. Monitoring oriental fruit moth (Lepidoptera: Tortricidae) with sticky traps baited with terpinyl acetate and sex pheromone. Journal of Applied Entomology 137:275-281.

Durden, K., J. Brown, and M.A. Pszczolkowski. 2008. Extracts of Ginkgo biloba or Artemisia species reduce feeding by neonates of codling moth, Cydia pomonella (Lepidoptera: Tortricidae), on apple in a laboratory bioassay. Journal of the Entomological Society of British Columbia 105:83-88.
Durden, K., S. Sellars, B. Cowell, J.J. Brown, and M.A. Pszczolkowski. 2011. Artemisia annua extracts, artemisinin and 1,8-cineole prevent fruit infestation by major, cosmopolitan pest of apples. Pharmaceutical Biology 49:563-568.

Durden, K., S. Sellars, and M. Pszczolkowski. 2009. Preventing fruit infestation by codling moth neonates with Artemisia extracts. Pestycydy/Pesticides 1:51-56.

Hamamura, Y., and K. Naito. 1961. Food selection by silkworm larvae, Bombyx mori: citral, linalyl acetate, linalool, and terpinyl acetate as attractants of larvae. Nature 190:879-880.

Hummelbrunner, L.A., and M.B. Isman. 2001. Acute, sublethal, antifeedant, and synergistic effects of monoterpenoids essential oil compounds on the tobacco cutworm Spodoptera litura (Lep., Noctuidae). Journal of Agricultural and Food Chemistry 49:715-720.

Il'ichev, A.L., S. Kugimya, D.G. Williams, and J. Takabayashi. 2009. Volatile compounds from young peach shoots attract males of oriental fruit moth in the field. Journal of Plant Interactions 4:289-294.

Isman, M.B. 2000. Essential oils for pest and disease management. Crop Protection 19:603-608.

Isman, M.B. 2002. Insect antifeedants. Pesticide Outlook 13:152-157.

Isman, M.B. 2006. Botanical insecticides, deterrents and repellents in modern agriculture and an increasingly regulated world. Annual Review of Entomology 51:45-66.

Isman, M.B., J.A. Wilson, and R. Bradbury. 2008. Insecticidal activities of commercial rosemary oils (Rosmarinus officinalis) against larvae of Pseudaletia unipuncta and Trichoplusia ni in relation to their chemical compositions. Pharmaceutical Biology 46:82-87.

Ito, T., and I. Horie. 1962. Nutrition of the silkworm, Bombyx moriVII: An aseptic culture of larvae on semi-synthetic diets. Journal of Insect Physiology 8:569-578.

Jones, G.D.G. 1952. The responses of the honey-bee to repellent chemicals. Journal of Experimental Biology 29:372-386.

Kanat, M., and M.H. Alma. 2004. Insecticidal effects of essential oils from various plants against larvae of pine processionary moth, Thaumetopoea pityocampa (Schiff.) (Lepidoptera: Thaumetopoeidae). Pest Management Science 60:173-177.

Knight, A.L., T.E. Larsen, K. Ketner, R. Hilton, and L. Hawkins. 2008. Field evaluations of concentrated spray applications of microencapsulated sex pheromone for codling moth. Environmental Entomology 37:980-989.

Koul, O., J.S. Multani, S. Goomber, W.M. Daniewski, and S. Berlozecki. 2004. Activity of some non-azadirachtin limonoids from Azadirachta indica against lepidopteran larvae. Australian Journal of Entomology 43:189-195.

Koul, O., J.S. Multani, G. Singh, W.M. Daniewski, and S. Berlozecki. 2003. 6ß-Hydroxygedunin from Azadirachta indica, its potentiation effects with some nonazadirachtin limonoids in neem against lepidopteran larvae. Journal of Agricultural and Food Chemistry 51:2937-2942.

Koul, O., R. Singh, B. Kaur, and D. Kanda. 2013. Comparative study on the behavourial response and acute toxicity of some essential oil compounds and their binary mixtures to larvae of Helicoverpa armigera, Spodoptera litura and Chilo partellus. Industrial Crops and Products 49:428-436.

Kovanci, O.B. 2015. Co-application of microencapsulated pear ester and codlemone for mating disruption of Cydia pomonella. Journal of Pest Science 88:311-319.

Kovanci, O.B., N.A. Kumral, and T.E. Larsen. 2010. High versus ultra-low volume spraying of a microencapsulated pheromone formulation for codling moth control in two apple cultivars. International Journal of Pest Management 56:1-7. 
Kovanci, O.B., and J.F. Walgenbach. 2005. Monitoring the Oriental fruit moth with pheromone and bait traps in apple orchards under different management regimes. International Journal of Pest Management 51:273-279.

Krishnan, S., A.C. Kshirsagar, and R.S. Singhal. 2005. The use of gum arabic and modified starch in the microencapsulation of a food flavoring agent. Carbohydrate Polymers 62:309-315.

Landolt, P.J., R.W. Hofstetter, and L.L. Biddick. 1999. Plant essential oils as arrestants and repellents for neonate larvae of the codling moth (Lepidoptera: Tortricidae). Environmental Entomology 28:954-960

Lethmayer, C., H. Hausdorf, J. Altenburger, and S. Blümel. 2009 Trials of alternative codling moth (Cydia pomonella) control strategies in Austria. International Journal of Fruit Science 9:385-393.

Liu, S.S., Y.H. Li, and Y.G. Lou 2006. Non-host plant extracts reduce oviposition of Plutella xylostella (Lepidoptera: Plutellidae) and enhance parasitism by its parasitoid Cotesia plutellae (Hymenoptera: Braconidae). Bulletin of Entomological Research 96:373-378.

López, A., S. Castro, M.J. Andina, X. Ures, B. Munguía, J.M. Llabot, et al. 2014. Insecticidal activity of microencapsulated Schinus molle essential oil. Industrial Crops and Products 53:209-216.

Miresmailli, S., R. Bradbury, and M.B. Isman. 2006. Comparative toxicity of Rosmarinus officinalis L. essential oil and blends of its major constituents against Tetranychus urticae Koch (Acari: Tetranychidae) on two different host plants. Pest Management Science 62:366-371.

Nair, T.R., and M.G. Kutty. 2004. Cardamom (Elettaria cardamomum) in Kerala, India. p. 130-147. In Kusters, K., and B. Belcher (eds.) Forest products, livelihoods and conservation. Vol. 1. Asia. Center for International Forestry Research (CIFOR), Bogor, Indonesia.

Nerio, L.S., J. Olivero-Verbel, and E. Stashenko. 2010. Repellent activity of essential oils. Bioresource Technology 101:372-378.

Pszczolkowski, M.A., and J.J. Brown. 2005. Single experience learning in host fruit selection by lepidopteran larvae. Physiology and Behavior 86:168-175.

Romeo, F.V., S. De Luca, A. Piscopo, E. De Salvo, and M. Poiana. 2010. Effect of some essential oils as natural food preservatives on commercial grated carrots. Journal of Essential Oil Research $22: 283-287$
Sedy, K.A., and E.K. Koschier. 2003. Bioactivity of carvacrol and thymol against Frankliniella occidentalis and Thrips tabaci. Journal of Applied Entomology 127:313-316.

Shaikh, J., B. Rajesh, and S. Rekha. 2006. Microencapsulation of black pepper oleoresin. Food Chemistry 94:105-110.

Shorey, H.H., and R.L. Hale. 1965. Mass-rearing of the larvae of nine noctuid species on a simple artificial medium. Journal of Economic Entomology 58: 522-524.

Singh, R., O. Koul, P.J. Rup, and J. Jindal. 2009. Toxicity of some essential oil constituents and their binary mixtures against Chilo partellus (Lepidoptera: Pyralidae). International Journal of Tropical Insect Science 29:93-101.

Suomi, D., J.J. Brown, and R.D. Akre. 1986. Responses to plant extracts of neonatal codling moth larvae, Cydia pomonella (L.), (Lepidoptera: Tortricidae: Olethreutinae). Journal of the Entomological Society of British Columbia 83:12-18.

Tripathi, A.K., V. Prajapati, K.K. Aggarwal, and S. Kumar. 2001. Toxicity, feeding deterrence, and effect of activity of 1,8-cineole from Artemisia annua on progeny production of Tribolium castaneum (Coleoptera: Tenebrionidae). Journal of Economic Entomology 94:979-983.

Tripathi, A.K., S. Upadhyay, M. Bhuiyan, and P.R. Bhattacharya. 2009. A review on prospects of essential oils as biopesticide in insect-pest management. Journal of Pharmacognosy and Phytotherapy 1:52-63.

Tyson, R., H. Thistlewood, and G.J.R. Judd. 2007. Modelling dispersal of sterile male codling moths, Cydia pomonella, across orchard boundaries. Ecological Modelling 205:1-12.

van Tol, R.W.H.M., H.J. Swarts, A. Linden, and J.H. Visser. 2007. Repellence of the red bud borer Resseliella oculiperda from grafted apple trees by impregnation of rubber budding strips with essential oils. Pest Management Science 63:483-490.

Weiss, E.A. 2002. Spice crops. CABI Publishing, Wallingford, UK.

Wenninger, E.J., and P.J. Landolt. 2011. Apple and sugar feeding in adult codling moths, Cydia pomonella: effects on longevity, fecundity, and egg fertility. Journal of Insect Science 11:161.

Yi, X., J. Liu, P. Wang, M. Hu, and G. Zhong. 2014. Contacting is essential for oviposition deterrence of Rhodojaponin-III in Spodoptera litura. Archives of Insect Biochemistry and Physiology 86:122-136. 